\title{
Feasibility Study of a Small Standalone Marine Power Source
}

\author{
ZAHER AL BARAKEH, ALI M. EL-RIFAIE, RAYMOND GHANDOUR \\ College of Engineering and Technology \\ American University of the \\ Middle East \\ Egaila, KUWAIT
}

\begin{abstract}
This paper presents a preliminary technical feasibility of using marine current as a possible source of renewable energy production in Kuwait substituting fossil fuel based energy production. Kuwait sea water depth and velocity have been studied in order to obtain the most suitable location for such system. Topographical data collected from Kuwait Institute for Scientific Research for marine currents and seabed have been used in carrying on a simulation study of the proposed system where the possible power output has been estimated. An economical study comparing the implementation of a small standalone generator and the implementation of a marine current generator for a standalone application was carried out showing the advantages of the latter. This preliminary work will help to show that marine current energy is a viable source of energy.
\end{abstract}

Keywords-Marine power, Renewable Energy, cost reduction

Received: December 16, 2019. Revised: June 18, 2020. Accepted: June 23, 2020. Published: June 24, 2020.

\section{Introduction}

Currently, fossil fuels are the main sources for producing electricity in Kuwait. With the increase of fossil fuel price and the negative environmental effects of utilizing them, many countries around the world are moving towards more renewable energy sources in their energy mix to reduce greenhouse emissions and to cut their energy expenditures. In order to find new renewable energy sources, scientists were looking around the world for repeatable and reliable phenomena that can be utilized or harvested to produce energy such as solar radiation, wind speed and marine currents. Fig. 1 shows the global energy supply projection to 2055 [1].

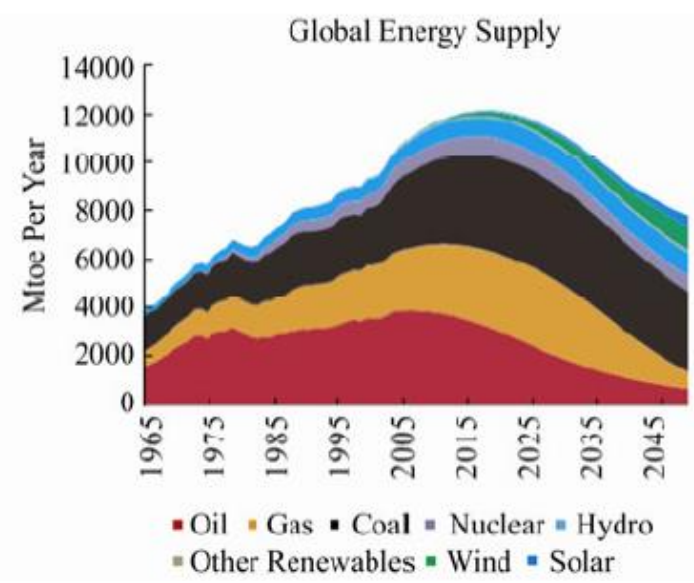

Fig. 1. Global energy supply projection to 2055 [1].

We can clearly identify the reduced use of fossil fuels or nuclear energy and so the increasing use of the renewable energies, especially after the global agreement on climate change signed in Paris 2015 [2].

Marine current and tidal waves is one of the promising renewable energy resources that are predictable and stable [3], they are created by the kinetic movement of water masses in seas and oceans and their movements have been studied for centuries. High and low tides and movement of water sea masses follow well known cycles defined by many constant factors, like the motion of the sun and the motion of the moon [4]. Therefore, this type of renewable energy would be very interesting to study and harvest. Until 2014 an estimate of 100 tidal energy companies operates worldwide half of which are in Europe, and the number is prone to increase [5] .

Extracting energy from marine power is not a new discovery as it was implemented years ago by different countries. One of the most famous and successful implementations was the "La Rance Tidal Power" in France. The station was constructed in 1966 with a capacity of $240 \mathrm{MW}$ [6]. The technology is getting into a new phase as many projects have been announced in the last several years. In South Korea for instance a huge project called Sihwa lake tidal project was setup and organized in 2011 with an estimated capacity of 254 MW [7]. Recent developments have been done in EU including an installed capacity of $188 \mathrm{GW}$ for ocean energy where $3.6 \mathrm{GW}$ are targeted for 2020 [8].

Other similar projects are being considered and constructed in different parts of the world. All these locations require a thorough mapping of sea beds to obtain the most suitable location for implementation in 
order to select the suitable turbines, machinery, and the optimum installation in order to insure the highest energy output with the least logistical complications [9]. To sum up, the potential of wave energy utilization for supplying a significant part of world energy needs is present but it needs to be combined with technologies that can maximize the extracted energy [10].

As the marine currents generated by the tidal motion and ocean circulation, the difference in temperature and the salinity may affect the produced current [11]. The physical properties are similar to the wind energy [12]. The power is function of the fluid density and the velocity [13]. The big difference between these sources is the fluid type. Since the density of the seawater is greater than the density of air, the generated marine power is higher than in wind energy by using devices with similar dimensions and assuming similar fluid velocities [14].

The predictability of the marine current energy is a major advantage over other renewable energy sources, in addition to the non-impact on the environment. These characteristics give the marine current energy an important potential in the future energy supply in many countries around the world [15].

Even though Marine current power is not widespread, it is a promising potential source of electricity and we will study its feasibility in Kuwait. We will utilize data collected from Kuwait Institute for Scientific Research (KISR) for marine currents and seabed in Kuwait to define the best location for such implementation. With the simulation and calculations done, this preliminary work will help to show that marine current energy is a viable source of energy and it can be harvested.

\section{Marine Current Power In Kuwait}

One of the advantages of tidal power is that it is fairly predictable and stable. In order to harvest the kinetic energy of water movement in seas, electric generator based on specific turbines are ought to be used. We can consider two types of water motion:

- Tidal streams: the motion of water masses due to tides. Generally, this movement is following a cycle that is repeated every day.

- Marine current, which is a unidirectional constant motion of water masses similar to rivers on land.

Kuwait is located at the top of the Persian Gulf. This gulf is a landlocked body of water except for a narrow strait in the south, the Strait of Hormuz. Due to the geography of this gulf, water is constantly flowing in a specific predictable manner.
In Kuwait, the deepest point in the sea is around $30 \mathrm{~m}$. This small depth would be a limiting factor in the power output since it will not allow large turbines to be installed. Therefore a specific type of turbines, hence generators, can be installed in these shallow waters called tidal stream generators [16]. These turbines can be simplified into submerged wind turbines since they are very similar in construction and design. Output power from these turbines is dependent on many factors like the density of water, water velocity and area across the blades. The higher the water density, the higher the power output is [17]. In this study, we will use a simplified horizontal axis turbine with 3 blades.

The extracted power from these stream generators can be obtained from the below equation [18]:

$$
\mathrm{P}=\rho^{*} \mathrm{~A} * \mathrm{~V} 3 * \mathrm{Cp} / 2
$$

Where:

$$
\begin{aligned}
& \mathrm{Cp}=\text { the turbine power coefficient } \\
& \mathrm{P}=\text { the power generated (watts) } \\
& \rho=\text { the density of the water }\left(1040 \mathrm{~kg} / \mathrm{m}^{3}\right) \\
& \mathrm{A}=\text { the sweep area of the turbine }\left(\mathrm{m}^{2}\right) \\
& \mathrm{v}=\text { the velocity of the flow }(\mathrm{m} / \mathrm{s})
\end{aligned}
$$

After studying the marine current power in the Arabian Gulf especially in Kuwait and looking into some previous implementations around the world, we pointed out the technical parameters that can meet our goal to construct a marine turbine in Kuwait. The location was chosen such that maximum power can be extracted from the site.

Using the given equation, we can calculate the maximum power output in 4 different locations chosen along the coast of Kuwait as shown in fig 2. Obtained power outputs are detailed in table 1 .

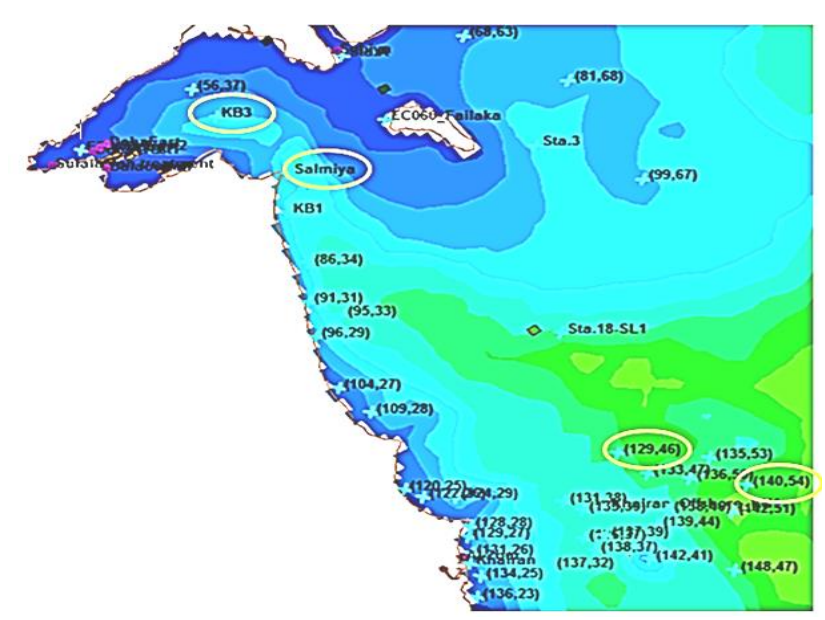

Fig. 2. Map Location and Depth 
Table 1. Chosen locations and their parameters

\begin{tabular}{|c|c|c|c|c|}
\hline location & $\begin{array}{c}\text { Depth } \\
(\mathbf{m})\end{array}$ & $\begin{array}{c}\text { Max } \\
\text { Turbine } \\
\text { Area } \\
\left.\mathbf{( m}^{2}\right)\end{array}$ & $\begin{array}{c}\text { Max } \\
\text { water } \\
\text { velocity } \\
(\mathbf{m} / \mathbf{s})\end{array}$ & $\begin{array}{c}\text { Max } \\
\text { Power } \\
\text { output } \\
(\mathbf{K w})\end{array}$ \\
\hline 1 & 15.50 & 41.852 & 1 & 9.7 \\
\hline 2 & 30.43 & 207.598 & 0.5 & 6.072 \\
\hline 3 & 6.56 & 152.533 & 0.5 & 4.461 \\
\hline 4 & 12.80 & 25.330 & 0.5 & 0.740 \\
\hline
\end{tabular}

All these values are obtained by using a power coefficient equal to 0.45 and a water density of 1040 $\mathrm{kg} / \mathrm{m} 3$ (all water constants and values are obtained from KSIR) [19].

It's important to note that power output varies with water depth. For example, the upper half of water depth will provide $75 \%$ of the output energy, while the lower half would provide $25 \%$ [20]. Therefore, we note that due to the shallowness of water in Kuwait, water depth would not be an interesting factor to follow and therefore we decided to use the location where water velocity is the highest instead of seeking the location with the maximum depth.

Hence, The Salmyia area was chosen as it has a higher marine current flow that reaches $1 \mathrm{~m} / \mathrm{s}$. As a result of the calculation, the diameter of the turbine blades was found to be $7.3 \mathrm{~m}$ with an area of 41.853 $\mathrm{m} 2$. The salinity of the water in the chosen site is $40 \mathrm{~g} / \mathrm{kg}$ and we consider the other parameters as shown in table 2 below.

Table 2: The parameter values chosen for Salmyia

\begin{tabular}{|c|c|c|c|c|}
\hline $\begin{array}{c}\text { Depth } \\
(\mathrm{m})\end{array}$ & $\begin{array}{l}\text { Velocity } \\
(\mathrm{m} / \mathrm{s})\end{array}$ & $\begin{array}{l}\text { Area of } \\
\text { turbine } \\
\left(\mathrm{m}^{\wedge} 2\right)\end{array}$ & $\begin{array}{l}\text { Water } \\
\text { Density } \\
\left(\mathrm{Kg} / \mathrm{m}^{\wedge} 3\right)\end{array}$ & $\begin{array}{l}\text { Power } \\
\text { Coefficient }\end{array}$ \\
\hline 15.5 & 1 & 41.853 & 1040 & 0.45 \\
\hline
\end{tabular}

The range of power coefficient $(\mathrm{Cp})$ in marine turbine is between 0.35 and $0.5 \mathrm{~m}$, for simplification reasons we have selected 0.45 .

\section{Discussion}

With the limited power output due the shallowness of the water we consider increasing the number of turbine to raise the capacity of electric power production, a multiple of stream generators must be installed creating a farm. The farm is assumed to have 17 turbines included within an area of one $\mathrm{Km} 2$ and therefore we can see in table 3 the estimated obtained power from one farm.
Table. 3: The systems of one stream generator and farm

\begin{tabular}{|c|c|c|}
\hline System features & $\begin{array}{c}\text { One stream } \\
\text { generator }\end{array}$ & $\begin{array}{c}\text { Farm } \\
\text { stream } \\
\text { generator }\end{array}$ \\
\hline $\begin{array}{c}\text { Power output } \\
\text { (Kw) }\end{array}$ & 9.79 & 166.43 \\
\hline $\begin{array}{c}\text { Total power } \\
\text { production } \\
\text { (MWh/year) }\end{array}$ & 14.959 & 254.31 \\
\hline
\end{tabular}

All calculations were carried out, using equation (1) and the collected data of the pertinent chosen locations (KSIR) for the four various locations which were available for two consecutive years. The below graphs shows the obtained power according to the given stream velocity on a typical day in Salmyia Location (Fig. 3), while Fig. 4 shows the average typical day of electrical power production.

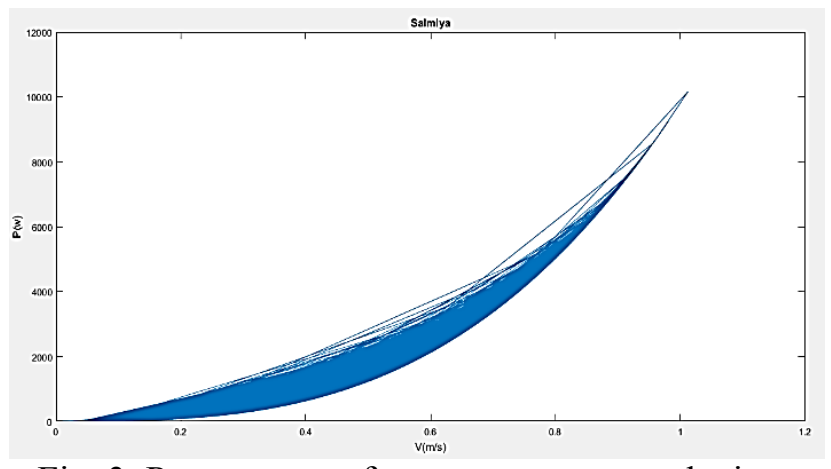

Fig. 3. Power output from water stream velocity at Salmyia location

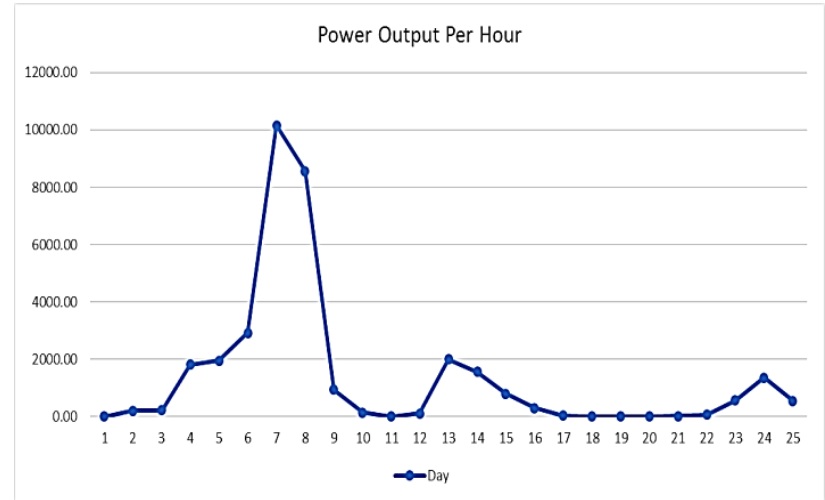

Fig. 4. Power output at Salmyia location on a typical day

We can notice from figure 3 that during that day, the maximum power output will peak around 7 AM where the tidal stream is at its peak and then drops in average to a low power output, especially at night. Therefore, a closer look at this graph will demonstrate the difficulty in utilizing this technique as a continuous and stable source of power. It can be noticed that the water velocity in the selected location would not provide the needed continuous kinetic energy as other locations around the world. However, it is considered 
enough to implement such a system. Fig. 5 represents the tidal velocity of the Salmyia location for one month, while fig. 6 shows data for one year for the same location. It is clear in fig. 5 and fig. 6 that sear water flow direction is bidirectional, and mostly flowing in opposite direction during the same day.

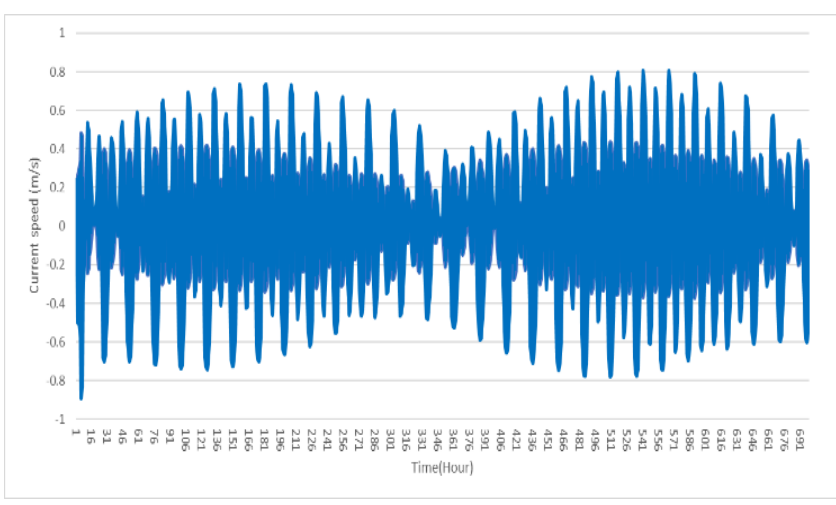

Fig. 5. Tidal velocity in Salmyia Location during one month.

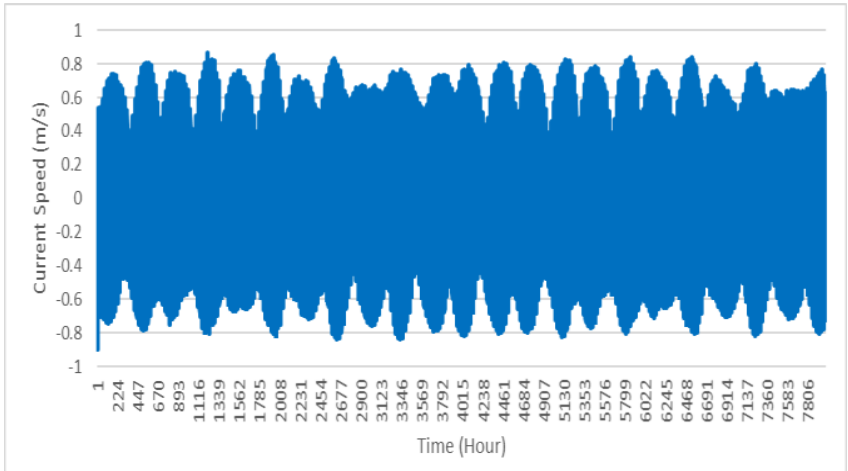

Fig. 6. Tidal velocity in Salmyia Location on a full Year.

A closer look at these graphs that detail current speed would show us the reproduction of these patterns, where everyday power output will peak at a certain time.

\section{Generator Simulation}

The aim of this system is to prove that we can get an output power using marine current power in a local context. In order to accomplish that, a power generated was simulated using Matlab Simulink [21]. The simulated system shown in figure 7 will uses the water stream speed as an input in order to calculate the power output of the generator. A comparison between the estimated and simulated output power was done to represent a real-life situation. Comparing the output power resulting from the generator simulation and the one obtained using equation (1) we can observe approximate similar results as shown in Fig. 8 where the curves follows similar patterns. A difference of almost $1 \mathrm{KW}$ of loss depending on the value of the load appears between the simulated and calculated values.

\section{Case Study of Telecom Tower System}

Due to the low power output of the generator, this technique cannot be used to produce a large amount of power for general applications. Therefore, a small standalone application can benefit more of this power production.

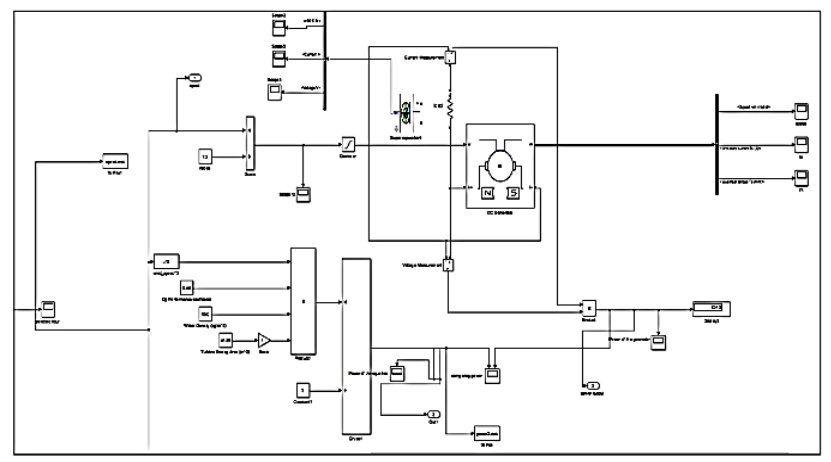

Fig. 7. Matlab Simulated generation system.

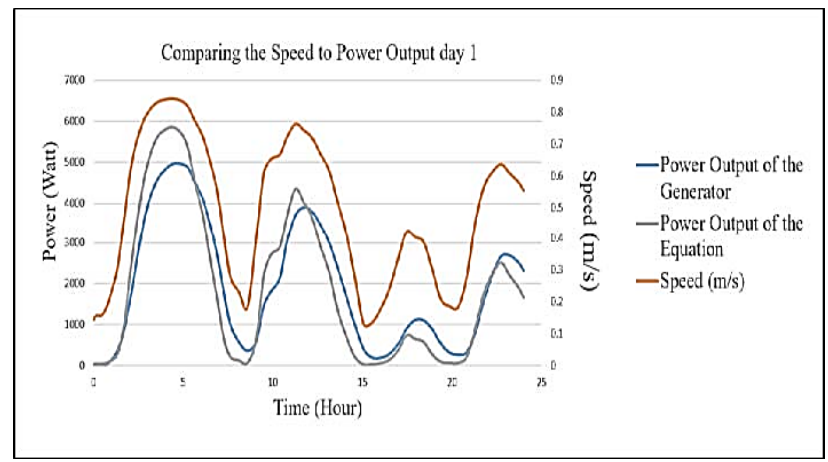

Fig. 8. Speed Vs Power output curves for simulated and calculated power

The sea front near Salmyia city is an active location for sea goers. This location shown in figure 9 is in front of Failaka Island would create a narrow strait of water where small and personal boat need to travel. One of the noticed aspect in these location is the absence of cell phone coverage due to its location far from any telecom tower. Therefore, we can consider using tidal currents as a renewable source of energy to power a telecom tower in order to provide cell phone coverage for boats passing this strait. In this case study, a telecom tower system will be supplied with electricity from the marine current system. The power that the system generates will be directly transferred to the specific load (telecom tower). This selected application requires a power supply of $8 \mathrm{Kw}$, the amount of power that a telecom power consumes. An economic study is 
done to compare between the utilization of such system, and the more traditional utilization of a diesel DC generator. In this part we will present the comparison between the fuel DC generator and the marine DC generator.

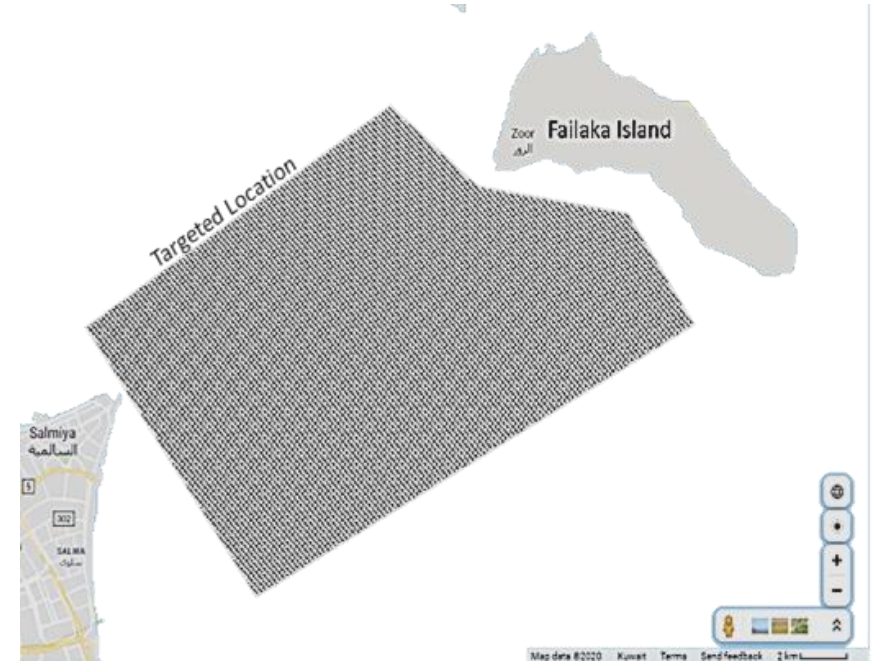

Fig. 9. Telecom Tower case study location

The main difference between the marine DC generator using marine generation turbine and the fuel DC generator, the generator works due to the water movement while the fuel generator consumes a specific amount of fuel. The nominal output power of the marine generator is $6.5 \mathrm{~kW}$. Whereas, the fuel generator produces an $8 \mathrm{~kW}$ power. Over the few years, the price of a diesel gallon has been between $0.36 \mathrm{KD}$ and 0.50 $\mathrm{KD}, \mathrm{KD}$ (Kuwaiti Dinar) being the unit of currency in Kuwait. A $0.47 \mathrm{KD} /$ gallon is used in the following calculations. The annual fuel consumption for the DC fuel generator will be around 9151.8740\$ after applying the price of conversion from local currency to USD $(1 \mathrm{KD}=3.27 \mathrm{USD})$ as explained in Table 4. The cost of the entire system of the marine generator is $90443 \$$ (obtained from local suppliers, and the cost of the fuel system is $18139.874 \$$. One thing that makes the marine DC generation system less reliable is that it needs more maintenance. However, the fuel generator must be checked constantly, so it needs from 2 to 12 visits per year. When the system is being examined, it will be shut down for a couple of hours, which means there will not be electricity provided, and backup generators will be needed which we did not include in our study.

Table 4: Comparison between two systems

\begin{tabular}{|c|c|c|}
\hline Components & $\begin{array}{c}\text { Cost of marine } \\
\text { DC generator }\end{array}$ & $\begin{array}{c}\text { Cost of fuel DC } \\
\text { generator }\end{array}$ \\
\hline Turbine & $80000 \$$ & - \\
\hline Generator & $3500 \$$ & $2245 \$$ \\
\hline $\begin{array}{c}\text { Fuel } \\
\text { consumption }\end{array}$ & - & $9151.8740 \$ /$ year \\
\hline Rectifier & $2168.3 \$$ & 2168.3 \\
\hline
\end{tabular}

\begin{tabular}{|c|c|c|}
\hline circuit & & \\
\hline Controller & $1347.7 \$$ & $1347.7 \$$ \\
\hline Battery & $700 \$$ & $700 \$$ \\
\hline Cables & $1727 \$$ & $1727 \$$ \\
\hline Maintenance & $1000 \$ /$ year & $800 \$ /$ year \\
\hline Total cost & $90,443 \$$ & $18,139.874 \$$ \\
\hline
\end{tabular}

At the time of installation, the cost of marine current generator is more expensive than that of a fossil fuel generator. But, according to the charts shown in Fig. 10 , the cumulated expenditure of the fuel DC generator is much higher than the marine DC generator. Taking into consideration 10 years of operation, the marine current generator would have costed less than a fuel generator. In a longer time of operation, the marine current would have provided a huge deduction in operation cost. It's worth mentioning that the price of a marine current generator is more stable, while a fuel generator will show an increasing in cost due to the usual change in price of fuel that is always expected to rise.

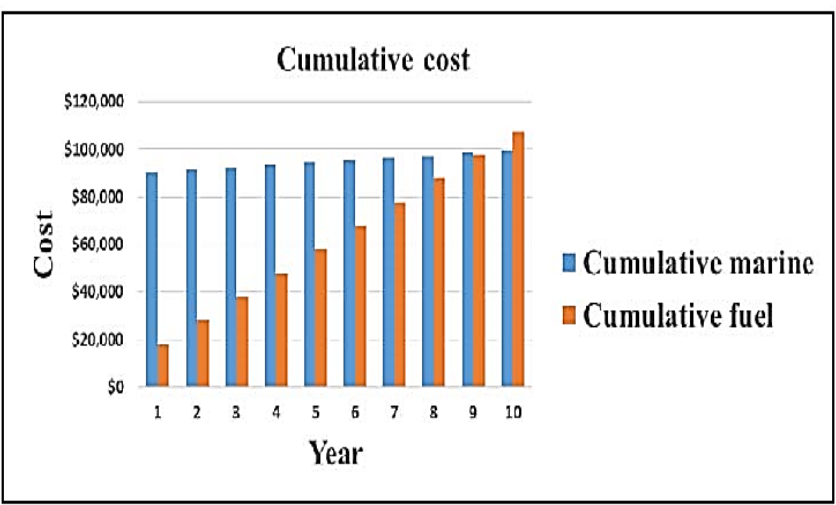

Fig. 10. Comparison between the cumulative cost of marine system and fuel system

\section{Conclusion}

As an oil producing country, oil and oil derivate fuel tend to be cheap. Therefore, energy production tends to mainly use fossil fuel for production purposes. As oil is a non-renewable source of energy it has its drawbacks. With the new trend of green energy and a cleaner energy production, other sources of energy are researched. As the demand on electricity is getting much higher, finding another source to produce electricity is a valid option. Marine current power is one of these successful options. In order to check its reliability as a source of energy, the marine power needed to be studied thoughtfully. In this paper, it was shown that a convenient amount of power can be collected using marine current power at least for small standalone applications. The total cost comparison carried out in this paper shows that implementing a marine current can provide an operation expenses cost deduction after almost 10 years of operation. 
References:

[1] M. M. El-Gohary, "Overview of Past, Present and Future Marine Power Plants", In Journal of Marine Science and Application, Vol. 12, pp. 219-227, 2013.

[2] R. Willis, "Paris 2015: getting a global agrrement on climate change", http://www.greenalliance.org.uk/resources/Paris, 2015.

[3] K. Touimi, M. Benbouzid and Z. Chen, "Optimal Design of a Multibrid Permanent Magnet Generator for a Tidal Stream Turbine", Energies 2020, 13, 487; doi:10.3390/en13020487, 2020.

[4] F. J. Charpentier, F. Mekri, S. B. Elghali, M. E. Benbouzid and T. Ahmed-Ali, "High-order sliding mode control of DFIG-based marine current turbine. In Industrial Electronics," IECON 2008. 34th Annual Conference of IEEE, pp. 1228-1233, 2008.

[5] J. R. Haslett, M. Garcia-Llorente, P. A. Harrisson, S. Li, P. M. Berry, "Offshore renewable energy and naturre conservation: the case of marine tidal turbines in Northern Ireland", Biodiversity And Conservation, Vol. 27, pp. 1619-1638, 2018

[6] V. De Laleu, "La Rance Tidal Power Plant. 40year operation feedback-lessons learnt," In Proceedings of the British Hydropower Association Annual Conference, pp. 1-40, October 2009.

[7] B. Oh, "Technology case study: Sihwa Lake tidal power station," 2 August 2016. [Online]. Available:https://www.hydropower.org/blog/techn ology-case-study-sihwa-lake-tidal-power-station.

[8] C. M. Johnstone, D. Pratt, J. A. Clarke and A. D. Grant, "A techno-economic analysis of tidal energy technology", Renewable Energy, vol. 49, pp. 101-106, 2013.

[9] I. N. Usachev, Yu. B. Shpolyanskii, B. P. Istorik, "Performance Control Of A Marine Power Plant In The Russian Arctic Coast And Prospects For The Wide-Scale Use Of Tidal Energy" Power Technology and Engineering, Vol. 38, No. 4, pp 188-193, 2004

[10] A. Pecher and J. P. Kofoed, "Handbook of Ocean Wave Energy", Volume 7, ISBN : 978-3319-39888-4, 2017.

[11] S. K. Chakrabarti and K. C. Subrata, "Ocean environment", in handbook of offshore engineering. London: Elsevier; p. 79-131, 2005.

[12] " F. O. Rourke, F. Boyle and A.Reynolds, "Renewable energy resources and technologies applicable to Ireland", Renewable and Sustainable Energy Reviews, vol. 13, no. 8, pp.1975-1984, 2009.

[13] M. Q. Lee, C. N. Lu and H. S. Huang, "Reliability and cost analyses of electricity collection systems of a marine current farm-A Taiwanese case study", Renewable and Sustainable Energy Reviews, vol. 13, no. 8, pp. 2012-2021, 2009.

[14] I. S. Hwang, Y. H. Lee and S. J. Kim, “ Optimization of cycloidal water turbine and the performance improvement by individual blade control", Applied Energy, vol.86, no. 9, pp.15321540. 2009.

[15] F. O. Rourke, F. Boyle and A. Reynolds, "Marine current energy devices: Current status and possible future applications in Ireland", Renewable and Sustainable Energy Reviews, vol. 14, pp.1026-1036, 2010.

[16] J. B. Johnson and D. J. Pride, "River, tidal, and ocean current hydrokinetic energy technologies: status and future opportunities in
Alaska." Prepared for Alaska Center for Energy and Power, 2010.

[17] Y. C. Chang, P. C. Chu and R. S. Tseng, "Site selection of ocean current power generation from drifter measurements," Renewable Energy, pp. 80, 737-745., 2015.

[18] G. Hagerman, B. Polagye, R. Bedard and M. Previsic, "Methodology for estimating tidal current energy resources and power production by tidal instream energy conversion (TISEC) devices," EPRI North American tidal in stream power feasibility demons, 2006.

[19] KSIR,http://www.kisr.edu.kw/en/publications/ periodical-reports/

[20] P. Mycek, B. Gaurier, G. Germain, G. Pinon and $\dot{E}$. Rivoalen, "Numerical and experimental study of the interaction between two marine current turbines," arXiv preprint arXiv:1310.4921, 2013.

[21] Matlab Simulink R2013

\section{Creative Commons Attribution License 4.0 (Attribution 4.0 International , CC BY 4.0)}

This article is published under the terms of the Creative Commons Attribution License 4.0 https://creativecommons.org/licenses/by/4.0/deed.en $\underline{\mathrm{US}}$ 